\title{
The Effectiveness of Xi Jinping's Metaphorical Discourse in Cross-Cultural Communication
}

\author{
Yanxia Zheng \\ Faculty of Foreign Languages, Huaiyin Institute of Technology, Huai'an, Jiangsu, China
}

\begin{abstract}
Metaphor is not only a linguistic and rhetorical phenomenon, but also an important cognitive and thinking mode, which plays an important role in the formation of human conceptual system. Conceptual metaphor theory holds that metaphor is the foundation of human conceptual system and the essence of metaphor is the mental mapping from source domain to target domain on the basis of similarities. In recent years, more and more metaphorical expressions can be found in Chinese President Xi Jinping's speeches, which have attracted wide attention of the researchers. This paper aims at exploring the effectiveness of Xi Jinping's metaphorical discourse from the perspective of cross-cultural communication. The study shows that the use of metaphor in political discourse helps to bring about novelty, break cultural barriers, enhance cultural identity, so as to enhance cross-cultural understanding and promote the effectiveness of cross-cultural communication. Conceptual metaphor provides an effective perspective for the study of political discourse, and also provides a new perspective for constructing China's communication discourse system to the foreign countries in the world.
\end{abstract}

Index Terms - political discourse, metaphor, effectiveness, cross-cultural communication

\section{INTRODUCTION}

International communication is not only a kind of stylized propaganda, but also a kind of discourse communication behavior with specific purpose and specific information. For a long time, China has developed a formulaic pattern of communication discourse to foreign countries, which ignores the special context and cross-cultural characteristics of international communication, and it is difficult to resonate with foreign audience, thus greatly reducing the effectiveness of communication.

However, in recent years, Xi Jinping, the General Secretary of the Communist Party of China (CPC) has improved this situation by using metaphors frequently in his speeches, which blows fresh wind into the field of political communication. Metaphor, as a way of rhetoric and cognition, is a means to construct the discourse of political speeches, which reflects the subjective consciousness of the speaker and guides the value judgment and behavior of the listeners. Xi's metaphorical discourses are very vivid and also very popular among people, for example, “老虎苍蝇一 起打” (“cracking down on both tigers and flies”) when talking about China's anti-corruption campaign, “照镜子、正衣 冠、洗洗澡、治治病” (“Looking in the mirror, getting dressed, taking a shower and healing”) when advocating the self-purification, self-perfection, self-innovation and self-improvement among the leaders and cadres in CPC, “像石榴 籽那样紧紧抱在一起” (“Clung together like pomegranate seeds”) when stressing the ethnic unity of Chinese peoples, and so on. It can be seen that metaphorical discourse has become an important part in the political discourse system of Chinese national leaders, and it is also fully proved that it plays a positive role in cross-cultural communication. The aim of this study is to explore the effectiveness of Xi Jinping's metaphorical discourse in cross-cultural communication.

\section{Metaphor: A Rhetorical Device And Cognitive Perspective}

In the traditional comparison view, metaphor is treated as a desirable rhetorical means. Aristotle (1965) describes metaphor as a borrowed term, a word substituted for another word, or a form of analogy that could be used to intensify the persuasive effect of an argument.

On the basis of the harsh criticism of the traditional view of metaphor, Lakoff and Johnson (1980) proposed their cognitive view of metaphor: metaphor is not just a way of expressing ideas by means of language, but a way of thinking about things, so that metaphor should be understood as "conceptual metaphor", which means that "our ordinary conceptual system is, in terms of which we both think and act, is fundamentally metaphorical in nature" and it is pervasive in everyday life (Lakoff \& Johnson, 1980, p.3). Lakoff and Johnson (1980) classify metaphor into three basic types: the structural metaphor, the orientational metaphor and the ontological metaphor, and it is a specific mental mapping from source domain to target domain on the basis of similarities. For example, LIFE IS A JOURNEY is a conceptual metaphor, in which "journey" is the source domain while "life" is the target domain; the category structure of "journey" is mapped onto "life" so that the abstract category of "life" can be understood easily.

From the perspective of cognitive linguistics, metaphor is a term with a broad sense, which includes similes, synecdoches, metonymies, personifications, and even proverbs as well. "Metaphors are powerful cognitive tools for our 
conceptualization of abstract categories" (Ungerer \& Schmid, 1996, p.114). Taylor (1989, p.132) also thinks that metaphor is a means whereby ever more abstract and intangible areas of experience can be conceptualized in terms of the familiar and concrete.

Moreover, "conceptual metaphor" is a very general concept, which is often implicit, usually undetected by people while the metaphors ubiquitous in daily life refer to the concrete forms of conceptual metaphor in language use, i.e. metaphorical expressions. For example: He's gone through a lot in life. He's without direction in his life. I'm at crossroads in my life, and so on are the metaphorical expressions of the conceptual metaphor LIFE IS AJOURNEY, which is usually written in capital letters.

\section{The Pragmatic Functions of Metaphor in Political Discourse}

Metaphor is the lifeblood of political discourse. Without metaphor, political expression would be impossible. In general, political discourse is rather dull, and has a lot of theories and terms that are difficult to understand, so it's hard to attract the attention of the public. Metaphor properly used in political discourse help form a unique language tone. Ren (2019) explores the pragmatic functions of metaphor in political discourse by analyzing the four types of conceptual metaphors in Xi Jinping's Talks on Building Clean Government and Anti-Corruption, and summarizes the two key functions of metaphor in political discourse, i.e. textual function and ideological function. Yuan (2020) holds that metaphors in political discourse have the functions of interpretation and persuasion. On the basis of their research, this study will focus on the two pragmatic functions of political discourse: coherent function and persuasive function.

\section{A. Coherent Function}

The use of conceptual metaphor can not only make political language more impressive and vivid, but also make the discourse structure more coherent. For example, in political discourse, national leaders tend to use the conceptual metaphor of "journey" to skillfully connect national development, government work and people's life experience, so as to inspire people's sense of identity.

Zhang (2018) studies coherence function of conceptual metaphors in President Xi Jinping's addresses and has found that "the systematicity and coherence of conceptual metaphor could contribute to discourse coherence. Conceptual metaphors in discourse were organized into a line that made the entire discourse complete and systematic" (p.49). A single metaphorical structure can construct textual coherence through its systematicity while the several metaphorical structures with the same source domain help construct a coherent discourse together.

\section{B. Persuasive Function}

Miller (1993) believes that the motivation for using metaphors in political discourse lies in its strong persuasive power. The use of metaphor in political discourse is of great benefit to the construction of political identity and discourse style and the exertion of its political persuasion function.

According to Schoor (2015), there are three main ways for metaphor to realize the persuasive function of political discourse, which is reason-based, emotion-based and strategy-based. In his view, metaphor in fact implies a cognitive reasoning process in political discourse, so it is easier to be understood and accepted by the audience when the speaker uses metaphor as the minor premise of discourse persuasion. The political figures, by using metaph or in the form of proverbs and common sayings in their speeches, can often achieve an effective persuasive result in political discourse.

\section{An Analysis of Xi JinPing’s Metaphorical Discourse: A Cross-Cultural Perspective}

In Xi Jinping's speeches, metaphor is widely used, which functions as an effective means to promote the cross-cultural communication. The detailed analysis with examples is as follows.

\section{A. Bring about Novelty}

Metaphorical thinking ability is a kind of creative thinking ability, which is an advanced stage of cognitive development (Zhao, p.102). Lakoff and Johnson (1980, p.55) distinguish dead metaphors (or conventional metaphors) from live metaphors (or novel metaphors). The live metaphors reflect the creativity of the speaker, i.e. creating a similar connection between two seemingly unrelated things, which is the very essence of metaphor. By using metaphor, we can talk about abstract and complex thoughts with specific and simple things, which can make the political discourse accurate and concise, and make its content vivid and novel. It is well proved that metaphorical discourse helps to arouse the inner feelings of the public and promote the public understanding of government policies.

Example 1:

“鞋子合不合脚, 自己穿了才知道。”一个国家的发展道路合不合适, 只有这个国家的人民才最有发言权。 (2013 年 3 月 23 日, 习近平在莫斯科国际关系学院的演讲)

On March 23, 2013, when Chinese President Xi Jinping delivered a speech at the Moscow Institute of International Relations, he said, “鞋子合不合脚, 自己穿了才知道。”(You never know whether your shoes fit you until you wear them.), which is a common saying drawn from people's actual life experience about shoes and feet matching problem. On such an international occasion, the purpose of Xi Jinping quoting this saying is to tell the world that Chinese people are wise enough to have their own choices and path to develop their countries. In Example 1, people's life experience 
about wearing shoes (source domain) is mapped onto China's development (target domain), which has clearly conveyed to the world our firm confidence in adhering to the path of socialism with Chinese characteristics.

Every country has its own historical and cultural background, and what suits it is the best. "You never know whether your shoes fit you until you wear them." Of course, the person standing next to you can make a comment on your shoes, but he is only an observer. We will not comment on whether other countries" "shoes" are good or not, and we also hope that others will not arbitrarily judge whether our "shoes" fit our feet. Only the Chinese people can judge the outcome of the choices made by the Chinese people and the path China has taken on its own.

Example 2

如果说创新是中国发展的新引擎, 那么改革就是必不可少的点火器, 要采取更加有效的措施把创新引擎 全速发动起来。(2014 年 11 月 9 日, 习近平在亚太经合组织工商领导人峰会开幕式上的演讲)

At the opening ceremony of the APEC CEO Summit on November 9, 2014, Xi Jinping made a speech, saying that "if innovation is the new engine driving China's development, then reform is an indispensable igniter. We need to take more effective measures to kick-start the engine of innovation at full speed.” In Example 2, “新引擎” (new engine) and “点火器” (igniter) indicate that the conceptual metaphor A COUNTRY IS A MACHINE is involved. The characteristics of the source domain "machine" is mapped onto the target domain "country", in which making a country get running is similar to operating a machine. We not only need to know the components of a machine (departments in a country), but also need to follow its fixed order (steps of a country' development). Therefore, by saying that reform is the igniter of the machine, Xi Jinping vividly conveys that reform is the first step of innovation.

In the above two examples, with the help of metaphor, Xi Jinping not only clarified his own views and attitudes, but also left a vivid and deep impression on the audience. It can be seen that the metaphorical discourse has achieved a rather good effect in the cross-cultural communication, and also has given the audience a sense of novelty.

\section{B. Breaking Cultural Barriers}

Conceptual metaphor helps people construct shared experience and perception, thus creating a close relationship between the government and the people and shortening the psychological distance of the audience.

In cross-cultural communication activities, the differences between Chinese and foreign cultures tend to make the audience have a sense of distance psychologically, which is not conducive to the expected communication effect of both sides. However, if the metaphorical discourse is consciously used to try to invoke the cultural images familiar to the target audience, it can effectively bridge the cultural gap, produce an affinity effect on the audience, and thus improve the effectiveness of the political discourse.

Example 3:

中国和印尼关系发展, 如同美丽的梭罗河一样, 越过重重山峦奔流向海, 走过了很不平凡的历程。(2013

年 10 月 3 日, 习近平主席在印尼国会演讲)

On October 3, 2013, when addressing in the Indonesian Parliament, Xi Jinping said, "The development of China-Indonesia relations, just like the beautiful Solo River, has traversed numerous mountains and rushed to the sea, and has gone through an extraordinary journey”. In Example 3, Xi Jinping borrowed a well-known Indonesian folk song "Beautiful Solo River", and successfully constructed a clever metaphor, which greatly shortened the psychological distance between the two sides, and made the audience more likely to have a sense of psychological affinity and the value of identity. In this example, the concept metaphor "RELATION DEVELOPMENT IS A RIVER" is involved the source domain "river" is mapped onto the target domain "relation development", which indicates that the development of relationship between China and Indonesia experienced a hard time, so that the abstract political discourse can be easily understood by the local audience.

Example 4:

今天的亚洲, 多样性的特点仍十分突出, 不同文明、不同民族、不同宗教汇聚交融, 共同组成多彩多姿 的亚洲大家庭。（2019 年 5 月 15 日，习近平在亚洲文明对话大会开幕式上发表主旨演讲）

On May 15, 2019, President Xi Jinping delivered a keynote speech at the opening ceremony of the Conference on Dialogue of Asian Civilizations. He said, "Today, Asia is still remarkable in its diversity. Different civilizations, different ethnic groups and different religions have come together to form a large and diverse Asian family." The concept metaphor A COUNTRY IS A FAMILY is involved in Example 4, in which "family" is the source domain and "country" is the target domain. The conceptual meaning of the source domain "family" lies in two aspects: one is geographic proximity; the other is the members in it are closely connected. The family members and close relationships in the source domain "family" are mapped onto countries and close relationships in the target domain "country", so by saying “亚洲大家庭” (Asian family), Xi Jinping wants to convey such information that the countries in Asia are friendly and closely related to each other in politics, economy and culture. The use of family metaphor helps to eliminate the alienation between countries and make them closer to each other. The use of this metaphor concretized and visualized the abstract relations of Asian countries, making it easier for the public to understand. At the same time, the metaphor of “大家庭” (big family) also reveals the long-cherished wish of the Chinese leaders to build a peaceful, harmonious and prosperous Asia, which should also be the common goal of all the countries in Asia.

\section{Enhancing Cultural Identity}


According to the theory of cognitive linguistics, metaphor is a common way of thinking and cognition of all human beings. People in the world have the same cognitive schemas and common cognitive structures, and they generally use familiar things to understand unfamiliar things, so that's why they can understand and recognize unknown things by mapping one cognitive domain onto another among different cultural groups.

Example 5:

拿破仑说过, 中国是一头沉睡的狮子, 当这头睡狮醒来时, 世界都会为之发抖。中国这头狮子已经醒了, 但这是一只和平的、可亲的、文明的狮子。（2014 年 3 月 27 日，习近平在中法建交 50 周年纪念大会 上的讲话)

On March 27, 2014, Chinese President Xi Jinping delivered a speech at the commemoration of the 50th anniversary of the establishment of diplomatic ties between China and France. When expounding in depth the connotation of the Chinese dream and its global significance, he said, "Napoleon once said that China is a sleeping lion, and when the lion wakes up, the whole world will tremble. China this lion has woken up, but it is a peaceful, amiable and civilized lion."

In Example 5, “中国是一头沉睡的狮子” (China is a sleeping lion) is a simile, in which China is compared to a lion — in the past China was a sleeping lion, but now although it has woken up, it is not a threat to any country either. This metaphor leaves some space for imagination and the image of a lion activates the same cognitive schema of different countries, which conforms to the general cognitive law of the target audience, so it is easily accepted, and thus promotes the cross-cultural identity.

Example 6:

新西兰有一句毛利谚语: “当你面向太阳, 阴影终将消散。”我们对人类合作战胜疫情充满信心, 对世界 经济复苏前景充满信心, 对人类共同美好的未来充满信心。（2021 年 7 月 16 日，习近平在亚太经合组 织领导人非正式会议上的讲话）

On July 16, 2021, Xi Jinping made a speech at the APEC Economic Leaders' Meeting which was held in New Zealand. At the end of the speech, he cited a Maori proverb in New Zealand, “当你面向太阳, 阴影终将消散。” (When you face the sun, the shadows will eventually disappear). As known to all, the sun gives off light and heat, so it usually symbolizes hope while the shadows stand for the darkness.

In Example 6, two conceptual metaphors are involved: THE SUN IS HOPE and THE BAD THINGS HAPPENED ARE SHADOWS. From the above example, we can see that "shadows" metaphorically refer to the epidemic situation of COVID-19 and the declining economy that the whole world is now confronted with. The two conceptual metaphors occur in the same context, conveying that when the members of the Asia-Pacific pull together and take actions positively in times of trouble and help each other, we will surely overcome the difficulties and usher in an even brighter future for humanity. By using the shared and familiar image of the sun, Xi Jinping successfully activates the common experience and cognition of people in different countries, which not only brings the hearts of audience together, but also makes them full of confidence in defeating COVID-19 and recovering the world economy, thus achieves a good persuasive effect.

From the above examples, we can see that people from different cultures have the same cognition about “太阳” (sun) and “阴影” (shadows), which means that they have the common cognitive characteristics and patterns, so that's why such metaphorical discourse can be easily understood and accepted by the audience and can help achieve strong communication effectiveness in the cross-cultural communication.

\section{CONCLUSION}

This paper is intended to explore the positive role of metaphorical discourse in cross-cultural communication. By studying and analyzing some metaphorical discourses in Xi Jinping's speeches, it can be found that due to the cross-domain mapping feature of metaphor, the use of metaphor in political discourse helps to bring about novelty, break cultural barriers, enhance cultural identity, so as to promote the cross-cultural understanding and increase the effectiveness of cross-cultural communication.

It can be concluded that appropriate use of metaphorical discourse in cross-cultural context is needed and necessary, and the wide spread and popularity of Xi Jinping's metaphorical discourse has well demonstrated it. Conceptual metaphor provides an effective perspective for the study of political discourse, and also provides a new perspective for constructing China's communication discourse system to the foreign countries in the world, which is worth a further study.

\section{ACKNOWLEDGEMENTS}

This work was financially supported by the Research Project of Humanities and Social Science in Huaiyin Institute of Technology "A Study of the Pragmatic Function of Xi Jinping's Metaphorical Discourse and Its English Translation" (Project Number: Z413I20507).

\section{REFERENCES}

[1] Aristotle. (1965). Poetics. In: Dorsch T. R. (ed. And transl.) Classical Literary Criticism. Harmondsworth: Penguin. 
[2] Lakoff, G. \& Johnson, M. (1980). Metaphor We Live By. Chicago: University of Chicago Press.

[3] Miller, G. A. (1993). Images and models, similes and metaphors. In: A. Ortony (ed.) Metaphor and Thought (2nd ed.). Cambridge: Cambridge University Press, 357-400.

[4] Ren, Lihua. (2019). On Construction and Pragmatic Functions of Conceptual Metaphor in the Honest and Clean Government Discourse Made by Xi Jinping. Journal of Jiangsu University of Technology, 6, 105-109.

[5] Schoor, C. (2015). Political metaphor, a matter of purposeful style: On the rational, emotional and strategic purposes of political metaphor. Metaphor and the Social World, 5 (1), 82-101.

[6] Taylor, J. R. (1989). Linguistic Categorization: Prototypes in Linguistic Theory. Oxford: Clarendon Press.

[7] Ungerer, F. \& H. J. Schmid. (1996). An Introduction to Cognitive Linguistics. London: Longman.

[8] Xi, Jinping. (2019). Deepening exchanges and mutual learning among civilizations, and jointly building an Asian community of shared future-A Keynote speech at the Opening Ceremony of the Conference on Dialogue of Asian Civilizations [OL]. http://politics.people.com.cn/n1/2019/0515/c1024-31086589.html. Aug. 6, 2021.

[9] Xi, Jinping. (2013). Following the trend of the times, and promoting world peace and development-A speech at the Moscow Institute of International Relations [OL]. http://www.gov.cn/ldhd/2013-03/24/content_2360829.htm. Aug. 1, 2021.

[10] Xi, Jinping. (2013) Working together to build a China-Asean community of shared future - A Speech in Indonesian Parliament [OL]. http://www.gov.cn/ldhd/2013-10/03/content_2500118.htm. July 28, 2021.

[11] Xi, Jinping. (2014). A Speech at the Commemoration of the 50th Anniversary of the Establishment of Diplomatic Relations between China and France [OL]. http://world.people.com.cn/n/2014/0328/c1002-24761852.html. Aug. 2, 2021.

[12] Xi, Jinping. (2021). Unity and Cooperation to Fight COVID-19 and Leading Economic Recovery-A speech at an informal meeting of APEC leaders [OL]. http://www.xinhuanet.com/world/2021-07/16/c_1127663536.htm. Aug. 6, 2021.

[13] Xi, Jinping. (2014). A Speech at the Opening Ceremony of the APEC CEO Summit [OL]. http://politics.people.com.cn/n/2014/1109/c1001-25999767-2.html. Aug. 1, 2021.

[14] Yuan, Zhuoxi. (2020). On Rhetorical Functions of Metaphor and its C-E Translation in Political Discourse. Journal of University of Shanghai for Science and Technology (Social Science Edition), 2, 114-119.

[15] Zhang, Yang. (2018). A Study on Coherence Function of Conceptual Metaphors in Chinese Discourse-A Case Study of President Xi Jinping's Addresses. MA thesis, Shanxi Normal University.

[16] Zhao, Yanfang. (2001). An Introduction to Cognitive Linguistics. Shanghai: Shanghai Foreign Language Education Press.

Yanxia Zheng was born in Huai'an, Jiangsu Province, China in 1968. She received her master degree in English Linguistics from Nanjing Normal University, Nanjing, Jiangsu Province, China in 2004.

She is currently an associate professor of English teaching in the Faculty of Foreign Languages at Huaiyin Institute of Technology. Her research interests include cognitive linguistics, pragmatics, translation, English teaching and research. 